\title{
Halomonas alimentaria sp. nov., isolated from jeotgal, a traditional Korean fermented seafood
}

\footnotetext{
1 Korea Research Institute of Bioscience and Biotechnology (KRIBB), PO Box 115, Yusong,

Taejon, Korea

2 Department of Food and Life Science,

Sungkyunkwan University, Chunchun-dong 300, Jangan-gu, Suwon, Korea

3 College of Veterinary Medicine, Chungnam National University, Taejon, Korea

4 Probionic Corporation, Bio-venture centre, KRIBB, PO Box 115, Yusong, Taejon, Korea
}

\author{
Jung-Hoon Yoon, ${ }^{1}$ Keun-Chul Lee, ${ }^{1}$ Yung Hee Kho, ${ }^{1}$ Kook Hee Kang, ${ }^{2}$ \\ Chul-Joong $\mathrm{Kim}^{3}$ and Yong-Ha Park ${ }^{1,4}$
}

Author for correspondence: Yong-Ha Park. Tel: +82 42860 4620. Fax: +82 428621315. e-mail: yhpark@mail.kribb.re.kr

\begin{abstract}
A Gram-negative, moderately halophilic bacterial strain, YKJ-16 ${ }^{\top}$, which was isolated from jeotgal, a traditional Korean food, was considered to be a member of the genus Halomonas. Cells of strain $\mathrm{YKJ}^{-16}{ }^{\top}$ are non-motile and cocci or short rods, unlike most Halomonas species. However, chemotaxonomic and phylogenetic analyses demonstrated that strain $\mathrm{YKJ}^{\mathrm{J}}{ }^{-16^{\top}}$ belongs to the genus Halomonas. The predominant isoprenoid quinone is ubiquinone-9. The major fatty acids are $C_{18: 1} \omega 7 c, C_{16: 0}, C_{19: 0} c y c l o \omega 8 c$ and $C_{16: 1} \omega 7 c$ and/or iso $C_{15: 0}$ 2OH. The phylogenetic tree showed that strain $\mathrm{YKJ}^{-16}{ }^{\top}$ forms a distinct evolutionary lineage within the radiation comprising Halomonas species and forms a coherent cluster with Halomonas halodenitrificans, Halomonas cupida and Halomonas pacifica. Levels of $16 \mathrm{~S}$ rDNA similarity between strain YKJ-16 ${ }^{\top}$ and the type strains of other Halomonas species are 93.0-96.3\%. Levels of DNA-DNA relatedness indicate a taxonomic status of strain $\mathrm{YKJ}^{-16^{\top}}$ as a species different from the three species that form the coherent cluster mentioned above. Morphologically, strain $\mathrm{YKJ}^{-16^{\top}}$ is also clearly differentiated from the type strains of $\boldsymbol{H}$. cupida and $\boldsymbol{H}$. pacifica. Accordingly, on the basis of the phenotypic characteristics, 16S rDNA sequence analysis and DNA relatedness data, strain $\mathrm{YKJ}^{-16}{ }^{\top}$ should be placed in the genus Halomonas as a novel species. The name Halomonas alimentaria sp. nov. is proposed with strain YKJ$1^{\top}\left(=\right.$ KCCM $\left.^{\top} 1042^{\top}=J C M 1088^{\top}\right)$ as the type strain.
\end{abstract}

Keywords: Halomonas alimentaria, sp. nov., polyphasic taxonomy, Korean traditional food, jeotgal

\section{INTRODUCTION}

The genus Halomonas was originally proposed, with the sole species Halomonas elongata, to accommodate a group of Gram-negative, rod-shaped and moderately halotolerant strains (Vreeland et al., 1980). The genus Deleya was created to accommodate some marine Alcaligenes species and Pseudomonas marina (Baumann et al., 1983). The species reclassified into the genus Deleya appear not to have been compared with Halomonas elongata, the sole species of Halomonas at

Abbreviations: ASW, artificial sea water; FAME, fatty acid methyl ester; MA, marine agar; TSA, trypticase soy agar.

The GenBank accession numbers for $16 \mathrm{~S}$ rDNA sequences of strain YKJ-16 ${ }^{\top}$ Halomonas canadensis DSM $6769^{\top}$ and Halomonas israelensis DSM $6768^{\top}$ are respectively AF211860, AF211861 and AF211862. that time. Accordingly, the genera Deleya and Halomonas were regarded as different genera of the family Halomonadaceae (Franzmann et al., 1989) and additional species were assigned to the two genera. The genus Halovibrio was created with a single species, Halovibrio variabilis, with a vibroid morphology isolated from Great Salt Lake, USA (Fendrich, 1988). Later, these three genera were observed to have similar properties from the results of chemotaxonomic characterization, in which cellular fatty acids, polar lipids and isoprenoid quinones were analysed (Franzmann \& Tindall, 1990). The species belonging to the genera Deleya, Halomonas and Halovibrio formed a monophyletic cluster in a phylogenetic tree based on $16 \mathrm{~S}$ rRNA gene sequences (Dobson et al., 1993; Dobson \& Franzmann, 1996). Also, Miller et al. (1994) identified the misclassification of Paracoccus halodenitrificans, 
the results of $16 \mathrm{~S}$ rDNA sequence comparison indicating that the species is phylogenetically related to the family Halomonadaceae. The genera Deleya, Halomonas and Halovibrio were subsequently unified into a single genus Halomonas and the misclassified Paracoccus halodenitrificans was transferred to the genus Halomonas (Dobson \& Franzmann, 1996). There are currently more than 20 validly described Halomonas species.

The revised genus Halomonas comprises Gram-negative, straight or curved rod-shaped, slightly or moderately halophilic, halotolerant and alkaliphilic bacteria (Berendes et al., 1996; Dobson \& Franzmann, 1996). The species assigned to this genus are aerobic but some are facultatively anaerobic in the presence of nitrate (Dobson \& Franzmann, 1996). This genus is characterized chemotaxonomically by the presence of major amounts of fatty acids $\mathrm{C}_{16: 1}$ plus $\mathrm{C}_{17: 0}$ cyclo, $\mathrm{C}_{16: 0}$ and $\mathrm{C}_{18: 1}$ plus $\mathrm{C}_{19: 0}$ cyclo and ubiquinone 9 (Q9) as the predominant isoprenoid quinone (Dobson \& Franzmann, 1996). This genus is included within the family Halomonadaceae, together with two other genera, Chromohalobacter and Zymobacter (Dobson \& Franzmann, 1996).

Recently, a Gram-negative, moderately halophilic bacterial strain, YKJ-16 ${ }^{\mathrm{T}}$, was isolated from jeotgal, a traditional Korean fermented seafood. This organism was considered to be a member of the genus Halomonas from the result of $16 \mathrm{~S}$ rDNA sequence comparison, but its cells were cocci or short rods, unlike most Halomonas species. All Halomonas species except Halomonas halodenitrificans have rod-shaped cells (Dobson \& Franzmann, 1996; Kocur, 1984). Accordingly, the aim of this work was to establish the exact taxonomic position of strain YKJ-16 ${ }^{\mathrm{T}}$ by additional phenotypic, phylogenetic and genomic characterization. In this study, the type strains of two Halomonas species, Halomonas canadensis DSM $6769^{\mathrm{T}}$ and Halomonas israelensis DSM $6768^{\mathrm{T}}$, the $16 \mathrm{~S}$ rDNA sequences of which had not been determined at the time of writing, were subjected to $16 \mathrm{~S}$ rDNA sequencing and then analysed phylogenetically.

\section{METHODS}

Bacterial strains and cultural conditions. Strain YKJ-16 $6^{\mathrm{T}}$ was isolated from jeotgal by the dilution-plating technique on trypticase soy agar (TSA) (BBL) supplemented with $\left(1^{-1}\right)$ $24 \mathrm{~g} \mathrm{NaCl}, 7 \mathrm{~g} \mathrm{MgSO}_{4} \cdot 7 \mathrm{H}_{2} \mathrm{O}, 5 \cdot 3 \mathrm{~g} \mathrm{MgCl}_{2}$. $6 \mathrm{H}_{2} \mathrm{O}, 0 \cdot 7 \mathrm{~g} \mathrm{KCl}$ and $0.1 \mathrm{~g} \mathrm{CaCl}_{2}$ (artificial sea water; ASW) (pH 7.5). For the investigation of morphological and physiological characteristics, strain YKJ-16 ${ }^{\mathrm{T}}$ was cultivated at $30^{\circ} \mathrm{C}$ on marine agar (MA) (Difco) or trypticase soy agar (TSA + ASW) and trypticase soy broth (TSB + ASW) supplemented with ASW. Cell mass for the analyses of the cell wall and menaquinones and for DNA extraction was obtained from TSB + ASW culture. The following Halomonas species were cultivated in TSB + ASW for DNA extraction: H. canadensis DSM $6769^{\mathrm{T}}$, Halomonas cupida DSM $4740^{\mathrm{T}}$, H. elongata DSM $2581^{\mathrm{T}}, H$. halodenitrificans DSM 735,$H$. israelensis DSM $6768^{\mathrm{T}}$ and Halomonas pacifica KCTC $2683^{\mathrm{T}}$. All strains were cultivated on a horizontal shaker at 150 r.p.m. and broth cultures were checked for purity before they were harvested by centrifugation. For fatty acid methyl ester (FAME) analysis, strain YKJ-16 $6^{\mathrm{T}}$ and some reference species were cultivated for $3 \mathrm{~d}$ at $30^{\circ} \mathrm{C}$ on MA and TSA + ASW. The reference strains included $H$. cupida DSM $4740^{\mathrm{T}}$, H. elongata DSM $2581^{\mathrm{T}}, H$. halodenitrificans DSM $735^{\mathrm{T}}$ and $H$. pacifica $\mathrm{KCTC} 2683^{\mathrm{T}}$.

Morphological and physiological characterization. Cell morphology was examined by phase-contrast microscopy and transmission electron microscopy (TEM). Flagellum type was examined with TEM using cells from exponentially growing culture. The cells were negatively stained with $1 \%$ $(\mathrm{w} / \mathrm{v})$ phosphotungstic acid and, after air drying, the grids were examined by using a model CM-20 transmission electron microscope (Philips). Catalase activity was determined by bubble production in a $3 \%$ hydrogen peroxide solution. Oxidase activity was determined by oxidation of $1 \% p$-aminodimethylaniline oxalate. Production of urease was determined as described previously (Cowan \& Steel, 1965). Hydrolysis of aesculin, casein, starch, Tween 80, tyrosine and xanthine was determined on MA with concentrations of substrates described previously (Cowan \& Steel, 1965; Lanyi, 1987). Tolerance of sodium chloride and growth at various temperatures were tested on TSA + ASW or TSB + ASW. Other physiological tests were performed with the API 20NE system (bioMérieux).

Isolation of DNA. Chromosomal DNA was isolated and purified according to the method described previously (Yoon et al., 1996), with the exception that ribonuclease T1 was used together with ribonuclease A.

Chemotaxonomic characterization. The presence or absence of diaminopimelic acid in the peptidoglycan was determined by the method described by Komagata \& Suzuki (1987). Menaquinones were analysed as described previously (Komagata \& Suzuki, 1987) using reversed-phase HPLC. For quantitative analysis of cellular fatty acid composition, a loop of cell mass was harvested and FAMEs were prepared and identified following the instructions of the Microbial Identification System (MIDI).

Determination of $\mathbf{G}+\mathbf{C}$ content. The $\mathrm{G}+\mathrm{C}$ content was determined by the method of Tamaoka \& Komagata (1984). DNA was hydrolysed and the resultant nucleotides were analysed by reversed-phase HPLC.

DNA-DNA hybridization. DNA-DNA hybridization was performed between strain $\mathrm{YKJ}-16^{\mathrm{T}}$ and the following Halomonas strains: $H$. cupida DSM $4740^{\mathrm{T}}, H$. halodenitrificans DSM $735^{\mathrm{T}}, H$. pacifica $\mathrm{KCTC} 2683^{\mathrm{T}}$ and $H$. elongata DSM $2581^{\mathrm{T}}$. DNA-DNA hybridization was performed fluorometrically by the method of Ezaki et al. (1989) using photobiotin-labelled DNA probes and microdilution wells.

$16 \mathrm{~S}$ rDNA sequencing and phylogenetic analysis. The $16 \mathrm{~S}$ rDNA was amplified by PCR using two universal primers as described previously (Yoon et al., 1998). The PCR product was purified by using a QIAquick PCR purification kit (Qiagen). The purified 16S rDNA was sequenced using ABI PRISM BigDye Terminator cycle sequencing ready reaction kit (Applied Biosystems) as recommended by the manufacturer. The purified sequencing reaction mixtures were electrophoresed automatically using an Applied Biosystems model 310 automatic DNA sequencer. The 16S rDNA sequence of strain YKJ-16 $6^{\mathrm{T}}$ was aligned with 16S rRNA gene sequences of Halomonas species and some other related taxa by using the CLUSTAL w software (Thompson et al., 


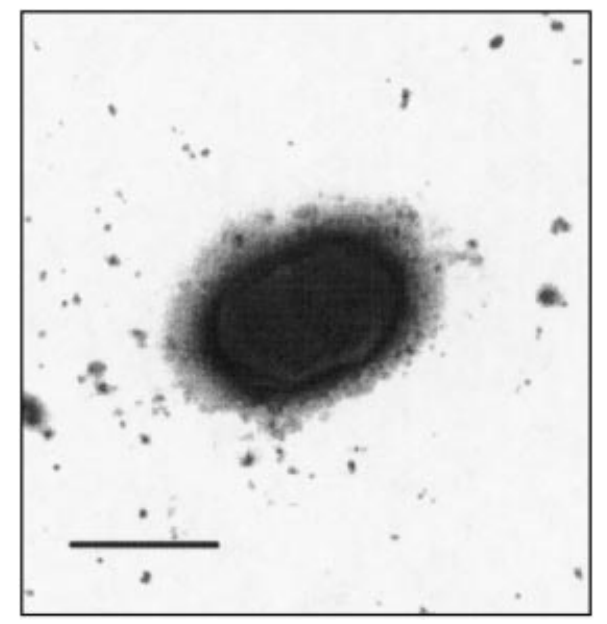

Fig. 1. Transmission electron micrograph of a short, rod-shaped cell of strain $\mathrm{YKJ}-16^{\top}$ from exponentially growing culture. Bar, $1 \mu \mathrm{m}$.

1994). 16S rDNA similarity values were calculated from the alignment. Gaps at the $5^{\prime}$ and $3^{\prime}$ ends of the alignment were omitted from further analyses. Evolutionary distance ma- trices were calculated by using the algorithm of Jukes \& Cantor (1969) with the DNADIST program within the PHYLIP package (Felsenstein, 1993). A phylogenetic tree was constructed by using the neighbour-joining method (Saitou \& Nei, 1987) as implemented within the NEIGHBOR program of the same package. The stability of relationships was assessed by a bootstrap analysis of 1000 datasets by using the programs SEQBOOT, DNADIST, NEIGHBOR and CONSENSE of the PHYLIP package.

Nucleotide sequence accession numbers. GenBank and EMBL accession numbers for reference $16 \mathrm{~S}$ rDNA sequences used in this analysis are given in Fig. 2.

\section{RESULTS}

\section{Morphological and physiological characteristics}

Strain YKJ-16 ${ }^{\mathrm{T}}$ was non-motile. Cells were cocci measuring $0.8-1.2 \mu \mathrm{m}$ in diameter or short rods measuring $0.8-1.2 \mu \mathrm{m}$ wide and $1.3-1.9 \mu \mathrm{m}$ long after $3 \mathrm{~d}$ of culture on TSA + ASW and MA. No flagella were found (Fig. 1). Strain YKJ-16 ${ }^{\mathrm{T}}$ showed a negative Gram-staining reaction. Colonies were smooth, glistening, circular and low-convex after $3 \mathrm{~d}$ of culture. The colour of colonies was cream-yellow on MA and dark yellow on TSA + ASW. No growth occurred on TSA. Strain YKJ-16 ${ }^{\mathrm{T}}$ grew on TSA $+\mathrm{ASW}$ and MA

Table 1. Differential phenotypic characteristics of strain $\mathrm{YKJ}-16^{\top}$ and some Halomonas species

Data not obtained in this study were taken from Baumann et al. (1983), Kersters \& De Ley (1984), Kocur (1984) and Quesada et al. (1984). Data in parentheses are those for the type strain from this study or from Baumann et al. (1983). All taxa are negative for hydrolysis of starch. +, Positive reaction; -, negative reaction; v, variable reaction; ND, not determined.

\begin{tabular}{|c|c|c|c|c|}
\hline Character & Strain YKJ-16 ${ }^{\mathrm{T}}$ & H. halodenitrificans & H. cupida & H. pacifica \\
\hline Cell morphology & Cocci or short rods & Cocci or short rods & Straight rods & Straight rods \\
\hline Flagellation & Absent & Absent & Peritrichous & Peritrichous \\
\hline Motility & - & - & + & + \\
\hline Oxidase & + & + & - & + \\
\hline Catalase & + & + & ND & ND \\
\hline $\begin{array}{l}\text { Reduction of nitrate } \\
\text { to nitrite }\end{array}$ & + & + & $\mathrm{v}(+)$ & - \\
\hline \multicolumn{5}{|l|}{ Hydrolysis of } \\
\hline Aesculin & - & - & + & - \\
\hline Casein & - & $(-)$ & $(-)$ & $(-)$ \\
\hline Gelatin & - & - & $(-)$ & $(-)$ \\
\hline Tween 80 & - & - & $(-)$ & $(-)$ \\
\hline Tyrosine & - & $(+)$ & $(+)$ & $(+)$ \\
\hline Urea & + & $(+)$ & $(+)$ & $(+)$ \\
\hline Xanthine & - & $(-)$ & $(-)$ & $(-)$ \\
\hline \multicolumn{5}{|l|}{ Growth at: } \\
\hline $4{ }^{\circ} \mathrm{C}$ & + & ND & - & - \\
\hline $40^{\circ} \mathrm{C}$ & + & ND & - & + \\
\hline $45^{\circ} \mathrm{C}$ & + & ND & - & $\mathrm{v}(+)$ \\
\hline Anaerobic growth & + & + & - & - \\
\hline $\mathrm{G}+\mathrm{C}$ content $(\mathrm{mol} \%)$ & 63 & $64-66$ & $60-63$ & $67-68$ \\
\hline
\end{tabular}


Table 2. Cellular fatty acid profiles of strain $\mathrm{YKJ}-16^{\top}$ and some Halomonas species

Values are percentages of total fatty acids. Fatty acid contents were determined from cells grown on MA and TSA + ASW as shown. Taxa are identified as: 1 , strain YKJ-16 ${ }^{\mathrm{T}} ; 2, H$. halodenitrificans DSM $735^{\mathrm{T}} ; 3$, H. cupida DSM 4740 ${ }^{\mathrm{T}} ; 4$, H. pacifica $^{2}$ KCTC $2683^{\mathrm{T}} ; 5$, H. elongata DSM $2581^{\mathrm{T}}$.

\begin{tabular}{|c|c|c|c|c|c|c|c|c|c|c|}
\hline \multirow[b]{2}{*}{ Fatty acid } & \multicolumn{2}{|r|}{1} & \multicolumn{2}{|r|}{2} & \multicolumn{2}{|r|}{3} & \multicolumn{2}{|r|}{4} & \multicolumn{2}{|r|}{5} \\
\hline & MA & $\mathbf{T S A}+\mathbf{A S W}$ & MA & $\mathbf{T S A}+\mathbf{A S W}$ & MA & $\mathbf{T S A}+\mathbf{A S W}$ & MA & $\mathbf{T S A}+\mathbf{A S W}$ & MA & $\mathbf{T S A}+\mathbf{A S W}$ \\
\hline \multicolumn{11}{|l|}{ Saturated fatty acids: } \\
\hline $\mathrm{C}_{10: 0}$ & $2 \cdot 4$ & $1 \cdot 9$ & $2 \cdot 4$ & - & $3 \cdot 1$ & $2 \cdot 8$ & $2 \cdot 3$ & $2 \cdot 4$ & $1 \cdot 9$ & $2 \cdot 7$ \\
\hline $\mathrm{C}_{10: 0} 3 \mathrm{OH}$ & $0 \cdot 2$ & $0 \cdot 2$ & $0 \cdot 2$ & - & $0 \cdot 1$ & $0 \cdot 2$ & $0 \cdot 2$ & $0 \cdot 3$ & $0 \cdot 2$ & $0 \cdot 9$ \\
\hline $\mathrm{C}_{12: 0}$ & - & - & - & $0 \cdot 6$ & $4 \cdot 0$ & $3 \cdot 9$ & $1 \cdot 5$ & $1 \cdot 6$ & $3 \cdot 2$ & $3 \cdot 6$ \\
\hline $\mathrm{C}_{12: 0} 2 \mathrm{OH}$ & $0 \cdot 1$ & $0 \cdot 1$ & - & - & $0 \cdot 2$ & $0 \cdot 2$ & $0 \cdot 1$ & $0 \cdot 1$ & $0 \cdot 1$ & $0 \cdot 1$ \\
\hline $\mathrm{C}_{12: 0} 3 \mathrm{OH}$ & $7 \cdot 0$ & $5 \cdot 2$ & $7 \cdot 2$ & $6 \cdot 9$ & $8 \cdot 5$ & $7 \cdot 1$ & $5 \cdot 6$ & $5 \cdot 9$ & $7 \cdot 1$ & $7 \cdot 5$ \\
\hline $\mathrm{C}_{14: 0}$ & $0 \cdot 7$ & $1 \cdot 2$ & $0 \cdot 2$ & $0 \cdot 4$ & $0 \cdot 3$ & $0 \cdot 2$ & $0 \cdot 3$ & $0 \cdot 2$ & $0 \cdot 2$ & $0 \cdot 1$ \\
\hline $\mathrm{C}_{15: 0}$ & $0 \cdot 3$ & $0 \cdot 6$ & - & $0 \cdot 1$ & $0 \cdot 1$ & $0 \cdot 1$ & $0 \cdot 2$ & $0 \cdot 2$ & $0 \cdot 2$ & $0 \cdot 1$ \\
\hline $\mathrm{C}_{16: 0}$ & $18 \cdot 7$ & $27 \cdot 0$ & $20 \cdot 4$ & $24 \cdot 7$ & $22 \cdot 0$ & $23 \cdot 4$ & $25 \cdot 3$ & $26 \cdot 0$ & $26 \cdot 7$ & $24 \cdot 8$ \\
\hline $\mathrm{C}_{16: 0} 3 \mathrm{OH}$ & - & - & - & - & - & - & - & - & $0 \cdot 3$ & $0 \cdot 2$ \\
\hline $\mathrm{C}_{17: 0}$ & $0 \cdot 3$ & $0 \cdot 2$ & $0 \cdot 4$ & $0 \cdot 2$ & $0 \cdot 5$ & $0 \cdot 6$ & $0 \cdot 2$ & $0 \cdot 4$ & $0 \cdot 2$ & $0 \cdot 3$ \\
\hline Iso $\mathrm{C}_{17: 0}$ & - & - & - & - & - & $0 \cdot 1$ & - & $0 \cdot 3$ & - & - \\
\hline $\mathrm{C}_{17: 0}$ cyclo & $1 \cdot 3$ & $5 \cdot 1$ & - & $0 \cdot 2$ & $2 \cdot 5$ & $0 \cdot 4$ & $2 \cdot 9$ & $1 \cdot 8$ & $5 \cdot 1$ & $2 \cdot 4$ \\
\hline $\mathrm{C}_{18: 0}$ & $0 \cdot 2$ & $0 \cdot 2$ & $0 \cdot 3$ & $0 \cdot 2$ & $0 \cdot 6$ & $0 \cdot 6$ & $0 \cdot 3$ & $0 \cdot 4$ & $0 \cdot 2$ & $0 \cdot 3$ \\
\hline $\mathrm{C}_{19: 0}$ cyclo $\omega 8 c$ & $7 \cdot 8$ & $12 \cdot 9$ & $2 \cdot 1$ & $0 \cdot 8$ & $15 \cdot 5$ & $1 \cdot 3$ & $18 \cdot 5$ & $14 \cdot 3$ & $28 \cdot 6$ & $12 \cdot 7$ \\
\hline \multicolumn{11}{|c|}{ Unsaturated fatty acids: } \\
\hline $\mathrm{C}_{17: 1} \omega 8 c$ & - & - & - & - & $0 \cdot 2$ & $0 \cdot 2$ & - & - & - & - \\
\hline $\mathrm{C}_{18: 1} \omega 7 c$ & $41 \cdot 4$ & $19 \cdot 4$ & $51 \cdot 3$ & $43 \cdot 4$ & $30 \cdot 7$ & $46 \cdot 2$ & $29 \cdot 8$ & $35 \cdot 3$ & $20 \cdot 1$ & $38 \cdot 4$ \\
\hline 11-Methyl $\mathrm{C}_{18: 1} \omega 7 c$ & $0 \cdot 4$ & $0 \cdot 4$ & - & - & $0 \cdot 3$ & - & $0 \cdot 5$ & $0 \cdot 4$ & $0 \cdot 4$ & $0 \cdot 1$ \\
\hline $\mathrm{C}_{18: 1} \omega 9 c$ & - & $0 \cdot 2$ & - & - & - & - & - & - & - & - \\
\hline $\mathrm{C}_{20: 2} \omega 6,9 c$ & - & $0 \cdot 2$ & - & - & $0 \cdot 2$ & - & $0 \cdot 3$ & $0 \cdot 2$ & $0 \cdot 4$ & $0 \cdot 1$ \\
\hline 10-Methyl fatty acids: & & & & & & & & & & \\
\hline $\mathrm{C}_{19: 0}$ & - & - & - & - & $0 \cdot 3$ & - & - & - & $0 \cdot 4$ & $0 \cdot 1$ \\
\hline \multicolumn{11}{|l|}{ Summed features:* } \\
\hline 3 & $19 \cdot 0$ & $24 \cdot 2$ & $15 \cdot 7$ & $22 \cdot 6$ & $10 \cdot 9$ & $12 \cdot 1$ & $11 \cdot 6$ & $9 \cdot 6$ & $4 \cdot 7$ & $4 \cdot 9$ \\
\hline 7 & $0 \cdot 3$ & $0 \cdot 9$ & - & - & - & - & - & - & - & - \\
\hline Unknown fatty acid(s) & - & $0 \cdot 1$ & - & - & $0 \cdot 3$ & $0 \cdot 5$ & $0 \cdot 5$ & $0 \cdot 6$ & $0 \cdot 2$ & $0 \cdot 3$ \\
\hline
\end{tabular}

* Summed features represent groups of two or three fatty acids that could not be separated by GLC with the MIDI system. Summed feature 3 contained one or more of $\mathrm{C}_{16: 1} \omega 7 c$ and/or iso $\mathrm{C}_{15: 0} 2 \mathrm{OH}$. Summed feature 7 contained one or more of an unknown fatty acid of ECL 18.846, $\mathrm{C}_{19: 0}$ cyclo $\omega 10 c$ and/or $\mathrm{C}_{19: 1} \omega 6 c$.

under anaerobic conditions. Strain $\mathrm{YKJ}-16^{\mathrm{T}}$ grew optimally in the presence of $1-13 \%(\mathrm{w} / \mathrm{v}) \mathrm{NaCl}$. It grew in the presence of $23 \% \mathrm{NaCl}$ but not in the presence of $0 \%$ or more than $24 \% \mathrm{NaCl}$. Strain YKJ$16^{\mathrm{T}}$ grew at 4 and $45^{\circ} \mathrm{C}$ but not at $50{ }^{\circ} \mathrm{C}$. The optimal growth temperature was $30^{\circ} \mathrm{C}$. The optimal $\mathrm{pH}$ for the growth was $6 \cdot 5-7 \cdot 5$ but growth was inhibited at $\mathrm{pH} 5 \cdot 0$. Strain YKJ-16 $6^{\mathrm{T}}$ had catalase and oxidase activities. Urea was hydrolysed but no hydrolysis of aesculin, casein, gelatin, starch, Tween 80, tyrosine or xanthine was observed. Nitrate was reduced to nitrite. Indole was not produced and arginine was not deaminated. Acid was not produced from glucose. Physiological properties are summarized in Table 1, together with those of the type strains of $H$. halodenitrificans, $H$. cupida and $H$. pacifica.

\section{Chemotaxonomic characteristics and DNA base composition}

Strain YKJ-16 ${ }^{\mathrm{T}}$ did not contain any diaminopimelic acid as the diagnostic amino acid in the cell wall peptidoglycan. The predominant isoprenoid quinone found in strain YKJ-16 $6^{\mathrm{T}}$ was ubiquinone with nine isoprene units (Q-9). The fatty acid patterns of cultures on TSA + ASW and MA were found to be similar for strain $\mathrm{YKJ}-16^{\mathrm{T}}$ and some Halomonas species, although some fatty acids, notably $\mathrm{C}_{18: 1} \omega 7 c$, differed in proportion between the two cultures (Table 2). Strain YKJ-16 ${ }^{\mathrm{T}}$ was characterized by having saturated and unsaturated fatty acids and no branched fatty acids. The major fatty acids found in strain $\mathrm{YKJ}-16^{\mathrm{T}}$ are $\mathrm{C}_{18: 1} \omega 7 c, \mathrm{C}_{16: 0}, \mathrm{C}_{19: 0}$ cyclo $\omega 8 c$ and $\mathrm{C}_{16: 1} \omega 7 c$ and/or 


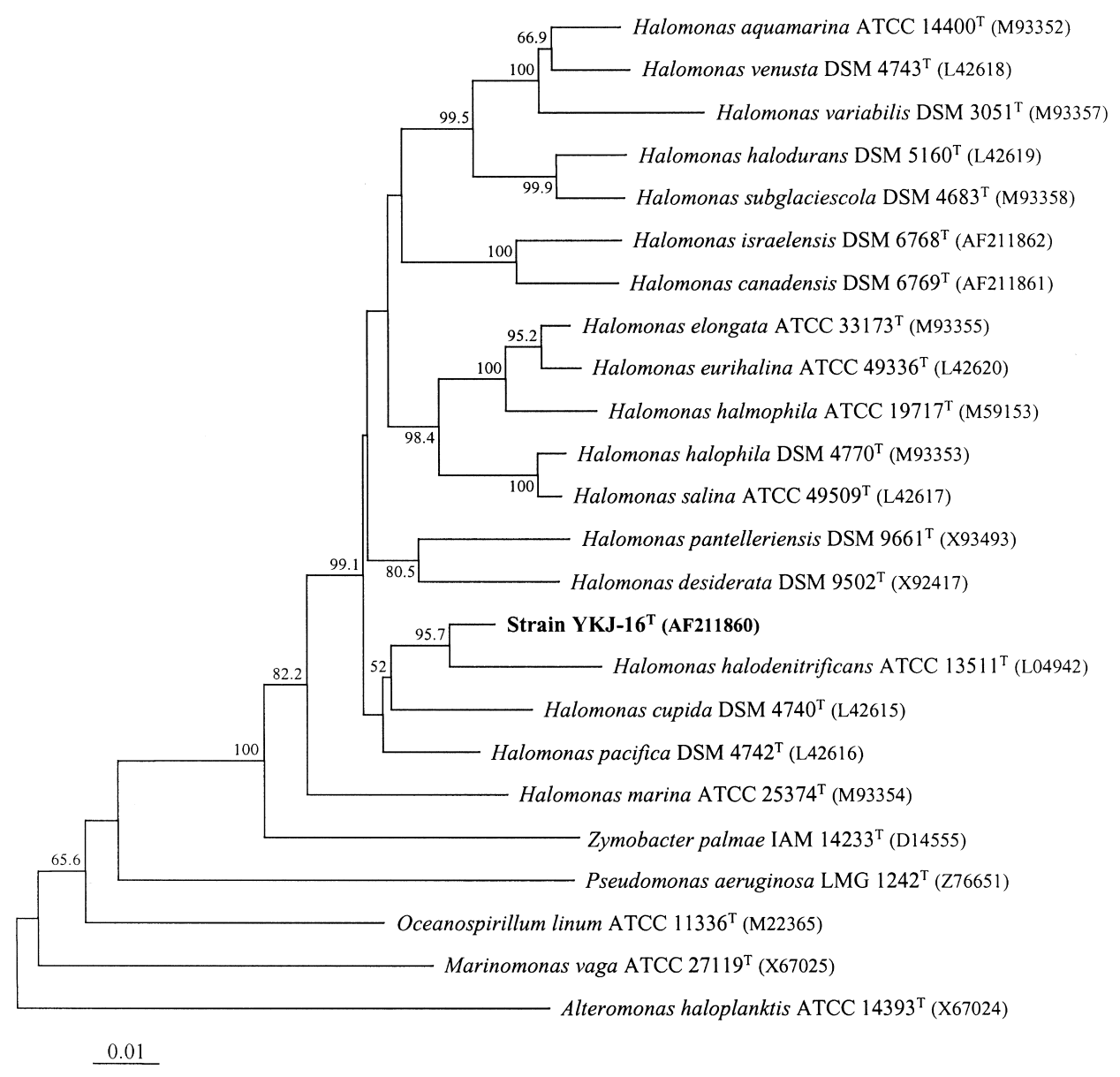

Fig. 2. Phylogenetic tree based on $16 \mathrm{~S}$ rDNA sequences showing the positions of strain $\mathrm{YKJ}-16^{\top}$, Halomonas species and some other related taxa. Bar, 0.01 substitutions per nucleotide position. Bootstrap values (expressed as percentages of 1000 replications) greater than $50 \%$ are shown at the branch points.

iso $\mathrm{C}_{15: 0} 2 \mathrm{OH}$ (Table 2). This fatty acid profile is similar to those shown by members of the genus Halomonas (Franzmann \& Tindall, 1990). The G+C content of strain YKJ-16 $6^{\mathrm{T}}$ was $63 \mathrm{~mol} \%$.

\section{Phylogenetic analysis}

Almost complete 16S rDNA sequences of strain YKJ$16^{\mathrm{T}}, H$. canadensis DSM $6769^{\mathrm{T}}$ and $H$. israelensis DSM $6768^{\mathrm{T}}$ were determined directly following PCR amplification and respectively comprised 1493, 1495 and 1492 nucleotides, representing approximately $96 \%$ of the Escherichia coli 16S rRNA sequence. The three sequences contain four signature nucleotide defined for the genus Halomonas and 15 signature nucleotides associated with the family Halomonadaceae, as described by Dobson \& Franzmann (1996). The phylogenetic tree showed that strain YKJ-16 ${ }^{\mathrm{T}}$ falls within the radiation of a cluster comprising Halomonas species (Fig. 2). Strain YKJ-16 ${ }^{\mathrm{T}}$ was found to form a coherent cluster with the type strains of $H$. halodenitrificans, $H$. cupida and $H$. pacifica and, in particular, the relationship between strain YKJ-16 ${ }^{\mathrm{T}}$ and $H$. halodenitrificans ATCC $13511^{\mathrm{T}}$ was supported by a high bootstrap resampling value of $95.7 \%$ (Fig. 2). Levels of 16S rDNA similarity between YKJ-16 ${ }^{\mathrm{T}}$ and the type strains of Halomonas species are $93 \cdot 0-97 \cdot 3 \%$. $H$. canadensis DSM $6769^{\mathrm{T}}$ and $H$. israelensis DSM $6768^{\mathrm{T}}$ were found to form phylogenetic lineages within the evolutionary radiation comprising Halomonas species. The level of $16 \mathrm{~S}$ rDNA similarity between $H$. canadensis DSM $6769^{\mathrm{T}}$ and $H$. israelensis DSM $6768^{\mathrm{T}}$ is $97 \%$ and the relationship between them is supported by a bootstrap resampling value of $100 \%$ (Fig. 2). $H$. canadensis DSM $6769^{\mathrm{T}}$ and $H$. israelensis DSM $6768^{\mathrm{T}}$ respectively exhibited levels of $16 \mathrm{~S}$ rDNA similarity of $93 \cdot 0-94 \cdot 9 \%$ and $93 \cdot 1-94.6 \%$ to the type strains of other Halomonas species.

\section{DNA-DNA relatedness}

DNA-DNA relatedness was assessed between strain YKJ $-16^{\mathrm{T}}$ and the type strains of some phylogenetically related Halomonas species and $H$. elongata DSM $2581^{\mathrm{T}}$, the type species of the genus. Strain YKJ-16 exhibited levels of DNA-DNA relatedness of $9 \cdot 2$, $13 \cdot 5,10 \cdot 2$ and $5 \cdot 7 \%$ with $H$. cupida DSM $4740^{\mathrm{T}}, H$. 
halodenitrificans DSM $735^{\mathrm{T}}$, H. pacifica $\mathrm{KCTC} 2683^{\mathrm{T}}$ and $H$. elongata DSM $2581^{\mathrm{T}}$.

\section{DISCUSSION}

In the course of monitoring micro-organisms present in the Korean fermented seafood jeotgal, we have isolated a large number of bacterial strains and characterized them taxonomically. Gram-positive, endospore-forming bacilli have been observed to predominate, but some Gram-negative bacteria were also found in the jeotgal. Of these isolates, one Gramnegative, coccoid or short rod-shaped strain (YKJ$16^{\mathrm{T}}$ ) attracted our attention and was applied to further taxonomic studies. Phylogenetic analysis based on the $16 \mathrm{~S}$ rDNA sequence assigns strain YKJ-16 ${ }^{\mathrm{T}}$ to the family Halomonadaceae, specifically to the genus Halomonas (Fig. 2). Strain YKJ-16 ${ }^{\mathrm{T}}$ forms a phylogenetic lineage within the evolutionary radiation encompassed by the genus Halomonas, particularly within the radiation of a cluster comprising $H$. halodenitrificans, $H$. cupida and $H$. pacifica (Fig. 2). The results obtained from physiological and chemotaxonomic analyses are consistent with the result of the phylogenetic classification. The genus Zymobacter, which has been placed in the family Halomonadaceae and includes a single species, Zymobacter palmae, is the closest phylogenetic neighbour of the genus Halomonas (Dobson \& Franzmann, 1996). The genera Halomonas and Zymobacter contain Q-9 as the predominant isoprenoid quinone and have similar fatty acid profiles (Franzmann \& Tindall, 1990; Okamoto et al., 1993). However, the two genera are known to be differentiated by the content of fatty acids $\mathrm{C}_{16: 0}$ and $\mathrm{C}_{16: 1}$ plus $\mathrm{C}_{17: 0}$ cyclo (Dobson \& Franzmann, 1996). The levels of $\mathrm{C}_{16: 0}$ in members of the genus Halomonas are $15 \cdot 5-32.0 \%$, whereas the mean level of $\mathrm{C}_{16: 0}$ in Zymobacter palmae is $51 \%$ (Franzmann \& Tindall, 1990; Okamoto et al., 1993). Members of the genus Halomonas contain 7.7-43.1\% $\mathrm{C}_{16: 1}$ plus $\mathrm{C}_{17: 0}$ cyclo, whereas Zymobacter palmae contains less than $0.5 \%$ $\mathrm{C}_{16: 1}$ plus $\mathrm{C}_{17: 0}$ cyclo (Franzmann \& Tindall, 1990; Okamoto et al., 1993). The fatty acid profiles of Halomonas species are mirrored by the result of fatty acid analysis of strain $\mathrm{YKJ}-16^{\mathrm{T}}$. Accordingly, strain YKJ-16 ${ }^{\mathrm{T}}$ can be differentiated from the genus Zymobacter by the composition of diagnostic fatty acids, as represented in Table 2. The genus Chromohalobacter, another member of the family Halomonadaceae, included only a single species, Chromohalobacter marismortui, at the time of writing. C. marismortui falls within the phylogenetic radiation comprising the Halomonas species, despite the conclusion of Mellado et al. (1995) that enough phenotypic differences exist between C. marismortui and the Halomonas-Deleya complex to support its position as a distinct genus. In our study, C. marismortui ATCC $17056^{\mathrm{T}}$ was found to be most closely related to $H$. canadensis DSM $6769^{\mathrm{T}}$ and $H$. israelensis DSM $6768^{\mathrm{T}}$, with respective levels of 16S rDNA similarity of 98.2 and $96.8 \%$. While this paper was in press, Arahal et al. (2001) proposed the transfer of $H$. canadensis and $H$. israelensis to the genus Chromohalobacter. In our opinion, a decision concerning whether Chromohalobacter represents a separate genus within the phylogenetic radiation of the genus Halomonas or should be included in the genus Halomonas should await additional taxonomic data, particularly chemotaxonomic data. Therefore, based on physiological and chemotaxonomic properties and phylogeny, strain YKJ-16 ${ }^{\mathrm{T}}$ should be placed in the genus Halomonas, despite its cellular morphology, which differs from that of most Halomonas species.

Strain YKJ-16 $6^{\mathrm{T}}$ exhibited the closest phylogenetic affinity to $H$. halodenitrificans, $H$. cupida and $H$. pacifica (Fig. 2). Levels of 16S rDNA similarity of strain YKJ-16 $6^{\mathrm{T}}$ to $H$. cupida DSM $4740^{\mathrm{T}}$, H. halodenitrificans ATCC $13511^{\mathrm{T}}$ and $H$. pacifica DSM $4742^{\mathrm{T}}$ are respectively $97 \cdot 0,97 \cdot 2$ and $97 \cdot 3 \%$. The cluster containing these species is differentiated from other Halomonas species by a high bootstrap resampling value of $99 \cdot 1 \%$. $16 \mathrm{~S}$ rDNA similarity values between strain $\mathrm{YKJ}-16^{\mathrm{T}}$ and other Halomonas species are in the range $93.0-96 \cdot 3 \%$, indicating that strain YKJ-16 cannot be assigned to any of these other species (Stackebrandt \& Goebel, 1994). Accordingly, comparative taxonomic studies were performed between strain $\mathrm{YKJ}-16^{\mathrm{T}}$ and $H$. halodenitrificans, H. cupida and $H$. pacifica in order to determine whether strain YKJ$16^{\mathrm{T}}$ could be considered as a novel species of the genus Halomonas or should be assigned to one of these three species. From its morphological and physiological properties, strain $\mathrm{YKJ}-16^{\mathrm{T}}$ appears to be most similar to H. halodenitrificans (Table 1). However, strain YKJ$16^{\mathrm{T}}$ and $H$. halodenitrificans DSM $735^{\mathrm{T}}$ exhibit differences in the proportions of some fatty acids, especially in the proportion of $\mathrm{C}_{18: 1} \omega 7 c$ on TSA $+\mathrm{ASW}$ culture. The level of DNA-DNA relatedness between strain YKJ-16 ${ }^{\mathrm{T}}$ and H. halodenitrificans DSM $735^{\mathrm{T}}$ is $13.5 \%$, which is low enough to consider them as different species (Wayne et al., 1987). Strain YKJ-16 ${ }^{\mathrm{T}}$ is differentiated morphologically and physiologically from $H$. cupida and $H$. pacifica (Table 1). In particular, the cellular morphology of strain YKJ-16 ${ }^{\mathrm{T}}$ is clearly distinguishable from those of the latter two species, which have rod-shaped and peritrichously flagellated cells. Moreover, levels of DNA-DNA relatedness support the position of strain $\mathrm{YKJ}-16^{\mathrm{T}}$ as a species different from $H$. cupida and $H$. pacifica. Accordingly, on the basis of differences in some phenotypic characteristics, phylogenetic inference and genetic distinctiveness, strain $\mathrm{YKJ}-16^{\mathrm{T}}$ should be placed as a novel species of the genus Halomonas, for which the name Halomonas alimentaria sp. nov. is proposed.

\section{Description of Halomonas alimentaria sp. nov.}

Halomonas alimentaria (a.li.men.ta'ri.a. L. adj. alimentaria relating to food).

Cells are cocci measuring $0 \cdot 8-1 \cdot 2 \mu \mathrm{m}$ in diameter or short rods measuring $0.8-1.2 \mu \mathrm{m}$ wide and $1.3-1.9 \mu \mathrm{m}$ long. Gram-staining reaction is negative. No flagella 
are found. Facultatively anaerobic. Colonies are smooth, glistening, circular and low-convex after $3 \mathrm{~d}$ of culture. Colour of colonies is cream-yellow on MA and dark yellow on TSA + ASW. Catalase- and oxidase-positive. Urea is hydrolysed. Aesculin, casein, gelatin, starch, Tween 80 , tyrosine and xanthine are not hydrolysed. Nitrate is reduced to nitrite. Indole is not produced. Arginine is not deaminated. Acid is not produced from glucose. Optimal $\mathrm{NaCl}$ concentration for growth is $1-13 \%(\mathrm{w} / \mathrm{v})$. Grows in the presence of $23 \% \mathrm{NaCl}$. No growth occurs in the presence of $0 \%$ or more than $24 \% \mathrm{NaCl}$. Growth occurs at 4 and $45^{\circ} \mathrm{C}$ but not at $50{ }^{\circ} \mathrm{C}$. Optimal growth temperature is $30^{\circ} \mathrm{C}$. Optimal pH for growth is $6 \cdot 5-7 \cdot 5$. Growth is inhibited below $\mathrm{pH} 5 \cdot 0$. The predominant isoprenoid quinone is Q-9. The major fatty acids are $\mathrm{C}_{18: 1} \omega 7 c$, $\mathrm{C}_{16: 0}, \mathrm{C}_{19: 0}$ cyclo $\omega 8 c$ and $\mathrm{C}_{16: 1} \omega 7 c$ and/or iso $\mathrm{C}_{15: 0}$ $2 \mathrm{OH}$. The $\mathrm{G}+\mathrm{C}$ content is $63 \mathrm{~mol} \%$ (determined by HPLC). Isolated from the traditional Korean fermented seafood jeotgal.

The type strain is strain $\mathrm{YKJ}-16^{\mathrm{T}}$, which has been deposited at the Korean Culture Center of Microorganisms as KCCM $41042^{\mathrm{T}}$ and at the Japan Collection of Microorganisms as JCM $10888^{\mathrm{T}}$.

\section{ACKNOWLEDGEMENTS}

This work was supported by grants HS2701 and HSS0310033 from the Ministry of Science and Technology (MOST) of the Republic of Korea and by the research fund of the Probionic Corporation of Korea.

\section{REFERENCES}

Arahal, D. R., García, M. T., Ludwig, W., Schleifer, K. H. \& Ventosa, A. (2001). Transfer of Halomonas canadensis and Halomonas israelensis to the genus Chromohalobacter as Chromohalobacter canadensis comb. nov. and Chromohalobacter israelensis comb. nov. Int J Syst Evol Microbiol 51, 1443-1448.

Baumann, L., Bowditch, R. D. \& Baumann, P. (1983). Description of Deleya gen. nov. created to accommodate the marine species Alcaligenes aestus, A. pacificus, A. cupidus, A. venustus, and Pseudomonas marina. Int J Syst Bacteriol 33, 793-802.

Berendes, F., Gottschalk, G., Heine-Dobbernack, E., Moore, E. R. B. \& Tindall, B. J. (1996). Halomonas desiderata sp. nov., a new alkaliphilic, halotolerant and denitrifying bacterium isolated from a municipal sewage works. Syst Appl Microbiol 19, $158-167$.

Cowan, S. T. \& Steel, K. J. (1965). Manual for the Identification of Medical Bacteria. London: Cambridge University Press.

Dobson, S. J. \& Franzmann, P. D. (1996). Unification of the genera Deleya (Baumann et al. 1983), Halomonas (Vreeland et al. 1980), and Halovibrio (Fendrich 1988) and the species Paracoccus halodenitrificans (Robinson and Gibbons 1952) into a single genus, Halomonas, and placement of the genus Zymobacter in the family Halomonadaceae. Int J Syst Bacteriol 46, 550-558.

Dobson, S. J., McMeekin, T. A. \& Franzmann, P. D. (1993). Phylogenetic relationships between some members of the genera Deleya, Halomonas, and Halovibrio. Int J Syst Bacteriol 43, 665-673.
Ezaki, T., Hashimoto, Y. \& Yabuuchi, E. (1989). Fluorometric deoxyribonucleic acid-deoxyribonucleic acid hybridization in microdilution wells as an alternative to membrane filter hybridization in which radioisotopes are used to determine genetic relatedness among bacterial strains. Int J Syst Bacteriol 39, 224-229.

Felsenstein, J. (1993). PHYLIP: Phylogenetic Inference Package, version 3.5. Department of Genetics, University of Washington, Seattle, WA, USA.

Fendrich, C. (1988). Halovibrio variabilis gen. nov. sp. nov., Pseudomonas halophila sp. nov. and a new halophilic aerobic coccoid Eubacterium from Great Salt Lake, Utah, USA. Syst Appl Microbiol 11, 36-43.

Franzmann, P. D. \& Tindall, B. J. (1990). A chemotaxonomic study of members of the family Halomonadaceae. Syst Appl Microbiol 13, 142-147.

Franzmann, P. D., Wehmeyer, U. \& Stackebrandt, E. (1989). Halomonadaceae fam. nov., a new family of the class Proteobacteria to accommodate the genera Halomonas and Deleya. Syst Appl Microbiol 11, 16-19.

Jukes, T. H. \& Cantor, C. R. (1969). Evolution of protein molecules. In Mammalian Protein Metabolism, vol. 3, pp. 21-132. Edited by H. N. Munro. New York: Academic Press.

Kersters, K. \& De Ley, J. (1984). Genus Alcaligenes Castellani and Chalmers 1919. In Bergey's Manual of Systematic Bacteriology, vol. 1, pp. 361-373. Edited by N. R. Krieg \& J. G. Holt. Baltimore: Williams \& Wilkins.

Kocur, M. (1984). Genus Paracoccus Davis 1969. In Bergey's Manual of Systematic Bacteriology, vol. 1, pp. 399-402. Edited by N. R. Krieg \& J. G. Holt. Baltimore: Williams \& Wilkins.

Komagata, K. \& Suzuki, K. (1987). Lipids and cell-wall analysis in bacterial systematics. Methods Microbiol 19, 161-203.

Lanyi, B. (1987). Classical and rapid identification methods for medically important bacteria. Methods Microbiol 19, 1-67.

Mellado, E., Moore, E. R. B., Nieto, J. J. \& Ventosa, A. (1995). Phylogenetic inferences and taxonomic consequences of $16 \mathrm{~S}$ ribosomal DNA sequence comparison of Chromohalobacter marismortui, Volcaniella eurihalina, and Deleya salina and reclassification of $V$. eurihalina as Halomonas eurihalina comb. nov. Int J Syst Bacteriol 45, 712-716.

Miller, J. M., Dobson, S. J., Franzmann, P. D. \& McMeekin, T. A. (1994). Reevaluating the classification of Paracoccus halodenitrificans with sequence comparisons of $16 \mathrm{~S}$ ribosomal DNA. Int J Syst Bacteriol 44, 360-361.

Okamoto, T., Taguchi, H., Nakamura, K., Ikenaga, H., Kuraishi, H. \& Yamasato, K. (1993). Zymobacter palmae gen. nov., sp. nov., a new ethanol-fermenting peritrichous bacterium isolated from palm sap. Arch Microbiol 160, 333-337.

Quesada, E., Ventosa, A., Ruiz-Berraquero, F. \& Ramos-Cormenzana, A. (1984). Deleya halophila, a new species of moderately halophilic bacteria. Int J Syst Bacteriol 34, 287-292.

Saitou, N. \& Nei, M. (1987). The neighbor-joining method: a new method for reconstructing phylogenetic trees. Mol Biol Evol 4, 406- 425 .

Stackebrandt, E. \& Goebel, B. M. (1994). Taxonomic note: a place for DNA-DNA reassociation and $16 \mathrm{~S}$ rRNA sequence analysis in the present species definition in bacteriology. Int $J$ Syst Bacteriol 44, 846-849.

Tamaoka, J. \& Komagata, K. (1984). Determination of DNA base composition by reverse-phase high-performance liquid chromatography. FEMS Microbiol Lett 25, 125-128. 
Thompson, J. D., Higgins, D. G. \& Gibson, T. J. (1994). CLUSTAL $\mathrm{W}$ : improving the sensitivity of progressive multiple sequence alignment through sequence weighting, position-specific gap penalties and weight matrix choice. Nucleic Acids Res 22, 4673-4680.

Vreeland, R. H., Litchfield, C. D., Martin, E. L. \& Elliot, E. (1980). Halomonas elongata, a new genus and species of extremely salttolerant bacteria. Int J Syst Bacteriol 30, 485-495.

Wayne, L. G., Brenner, D. J., Colwell, R. R. \& 9 other authors (1987). Report of the ad hoc committee on reconciliation of approaches to bacterial systematics. Int J Syst Bacteriol 37, 463-464.

Yoon, J.-H., Kim, H., Kim, S.-B., Kim, H.-J., Kim, W. Y., Lee, S. T., Goodfellow, M. \& Park, Y.-H. (1996). Identification of Saccharomonospora strains by the use of genomic DNA fragments and rRNA gene probes. Int $J$ Syst Bacteriol 46, 502-505.

Yoon, J.-H., Lee, S. T. \& Park, Y.-H. (1998). Inter- and intraspecific phylogenetic analysis of the genus Nocardioides and related taxa based on 16S rDNA sequences. Int J Syst Bacteriol 48, $187-194$. 